\title{
ФОРМУВАННЯ ПУБЛІЧНОГО ПРОСТОРУ СІЛ В АСПЕКТІ ОБ'ЄДНАННЯ ТЕРИТОРІАЛЬНИХ ГРОМАД
}

\section{PUBLIC SPACE FORMATION OF VILLAGES IN THE CONTEXT OF AMALGAMATED TERRITORIAL COMMUNITIES}

Парфентьсва І.О. к.т.н., доц, Мельник Ю.А. к.Т.н., доц, Гусачук Д.А. к.Т.Н., доц, Ільчук Н.І. к.т.н., доц (Луцький національний технічний університет)

Parfentieva I.O., Ph.D. in Engineering, Associate Professor, Melnyk Y.A. Ph.D. in Engineering, Associate Professor, Husachuk D.A. Ph.D. in Engineering, Associate Professor, Ilchuk N.I. Ph.D. in Engineering, Associate Professor (Lutsk National Technical University)

В статті проаналізовано принципи формування та особливості функціонування «публічних просторів» міста, з метою адаптації їх до сільських поселень в аспекті об'єднання територіальних громад. В результаті проведених досліджень було розроблено проекти формування так званих «сільських публічних просторів» різних адміністративних центрів ОТГ.

One of the main problematic issues faced by amalgamated territorial communities (ATC) is the formation of a united social and cultural space based on a newly formed community. As a solution to this issue, urbanists and sociologists proposed a phenomenon called "public space".

An important role in adapting of urban "public space" to the rural settlements is played by the principles of formation and functions that are performed by "public spaces". These centers of the existence and communication of the ATC inhabitants will ensure the development both of administrative centers of ATC and the community in general.

The article analyzes the principles of formation and functioning peculiarities of the "public spaces" of the city in order to adapt them to rural settlements in the context of ATC. As a result of research, the projects for "rural public spaces" formation of various ATC administrative centers were developed. These projects includes reconstruction and improvement of the territory of the central part of the 
villages of Zhydychyn and Knyahynynok of the Volyn region and the village of Boremel of the Rivne region.

During design these projects, the principles of the "public spaces" formation and the functions that they performed were taking into account as well as the methods and elements of the village center reconstruction. That are:

- improvement of the street network of the village in view of traffic safety; building of cycle tracks; installing of public transport stops; parking planning;

- combination of green plantations depending on their functional purpose;

- development of a recreation area for the inhabitants of the village;

- improvement of the territory for cultural events;

- building and improvement of the playground;

- styling in one architectural style of buildings located in the central part of the village.

The implementation of these projects will give an opportunity to develop the infrastructure of amalgamated territorial communities, attract tourists, and also improve the living conditions and rest of the inhabitants of these ATC.

Ключові слова: об'єднана територіальна громада, «публічний простір», «сільський публічний простір», благоустрій території, реконструкція, зелені насадження, центральна частина села.

Keywords: amalgamated territorial community, "public space", "rural public space", landscaping of the territory, green plantations, central part of the village.

Реформа децентралізації є однією з найуспішніших в Україні $[1,2,3]$. Децентралізація - це запорука ефективного територіального розвитку, шлях до демократизації, який вимагає вільних просторів для комунікації - місць формування громадської думки та участі громадян у житті села . Отже, місце для соціалізації, обміну думками та просто інноваційний відпочинок регенерований під сучасний темп життя - це публічний простір [4,5]. Одним 3 основних аспектів розвитку територіальної громади $\epsilon$ наявність комфортних і доступних публічних просторів. 
Публічний простір - це соціальний простір, який є відкритим i доступним для всіх. Він може існувати у вигляді: тротуарів, громадських площ, скверів, парків, пляжів, дворових територій, тощо [6].

Застосування поняття «публічного простору» має свої витоки із європейської традиції міських досліджень, для позначення прийнято використовувати термін «public space». Відповідно, «public space» розглядається в трьох основних аспектах: як відкритий простір для відпочинку, рекреації, охорони здоров'я; як простір дебатів; як доступний, відкритий простір - місця, доступні для всіх, або для різноманітних груп осіб, що базуються на основі соціальної свободи пересування та анонімності $[7,8]$.

Актуальність даної тематики зумовлена необхідністю вивчення принципів формування міських «публічних просторів» 3 можливістю їх адаптації до умов розвитку територій сіл в аспекті об'єднання територіальних громад.

\section{Основними завданнями с:}

- вивчення основних принципів формування та функцій «публічних просторів» міста та вивчення можливості їх адаптації до сільських територій;

- розробка проектів «сільських публічних просторів» 3 метою розвитку територіальних громад та покращення умов життя їх мешканців;

- вивчення можливостей використання основних принципів формування «публічних просторів» в сільських умовах.

Bce, що пов'язане з існуванням людини поза межами власного помешкання, споживання, щоденна комунікація - $\epsilon$ публічними i відбуваються у міському або сільському публічному просторі.

Він оточує нас практично всюди - на тротуарі, в парку, в громадському транспорті, на ринку, в музеї, в університетських аудиторіях і центрах сучасного мистецтва, в торгівельних центрах і в громадських приймальнях, а також у соціальних мережах та інтернет-форумах, які дозволяють поєднувати видиму приватність із публічною імматеріальністю віртуального простору.

Головними функціями публічних просторів $є$ :

- комунікаційна (місце для зустрічей, спілкування, самовираження, спільних святкувань);

- $\quad$ рекреаційна (місце для прогулянок, відпочинку); 
- політична (місце публічних зборів, дебатів, політичних протестів, соціальних рухів);

- $\quad$ територіальної ідентифікації та самоідентифікації (місце формування ідентичності, розвитку територіальних громад);

- розважальна (місце проведення фестивалів, культурно-масових заходів)

- шопінгу .

Врахувавши функції публічних просторів виділено три типи таких формувань:

- $\quad$ площі (майдан, ринкова площа) та вулиці 3 тротуарами (у т.ч. проспекти, бульвари, дороги);

- $\quad$ «зелені» публічні простори - парки, бульвари, сквери, а також набережні;

\section{- $\quad$ моли (торгово-розважальні центри).}

Публічні простори можуть бути відкритими або закритими, регульованими або хаотичними, можуть регулюватися державою або специфічними приватними інтересами [9].

Створення та утримання публічних просторів здійснюються задля i через громадян. Вони виховують вміння правильно проводити вільний час та викликають розуміння активного, соціального відпочинку [3, 7, 8]. Культурний обмін, активне соціальне життя, розвиток, спілкування - це результат успішного публічного простору в місті чи в селі.

Основними принципами формування публічного простору є:

- доступність - зв'язок 3 прилеглими околицями, помітність, легко дохідність або ж легкість потрапляння. Часто такі простори формуються при перетині великих потоків людей у фокусній зоні міста; в ньому розвинена система громадського транспорту, пішохідний зв'язок та є паркінг.

- комфорт та безпека - зручність розташування, забезпечення необхідним обладнанням, захист від зовнішнього впливу. Безпечний простір охороняється та освітлений в вечірній і нічний час;

- багатофункціональність - різний спектр розваг, залучення різних категорій, статусів та вікових груп населення

- $\quad$ естетика - гармонійність духовних структур людини або філософію художньої творчості. Атмосферу створює хороший дизайн та увага до деталей; 
- $\quad$ точка тяжіння - унікальна особливість простору інсталяції, вуличне мистецтво, скульптури, місце проведення фестивалів та ярмарків

- $\quad$ соціалізація - почуття приналежності до спільноти і до місця, яке сприяє видам соціальної активності [7].

Чим більше принципів якісного публічного простору враховано при проектуванні, тим популярнішою стане територія серед мешканців міста, села та туристів. Основними функціями, які виконує «сільський публічний простір» можна вважати: комунікаційну, рекреаційну, політичну, розважальну. Тобто в якості таких осередків можуть виступати: площі, вулиці 3 тротуарами, парки, сквери, майданчики.

Отже, публічний простір - це багатовимірна сфера взаємодії громадського суспільства та політичної влади, місце дії та взаємодії відносно замкнутих сфер: економічної, політичної, культурної, у кожній з яких існують свої правила комунікації.

В якості дослідження формування «сільського публічного простору» в аспекті об'єднання територіальних громад були вибрані новостворені сільські ОТГ Волинської та Рівненської області, а саме Жидичинська, Княгининівська та Боремельська.

1. Основним об'єктом створення публічного простору с. Жидичин є реконструкція території біля будинку культури.
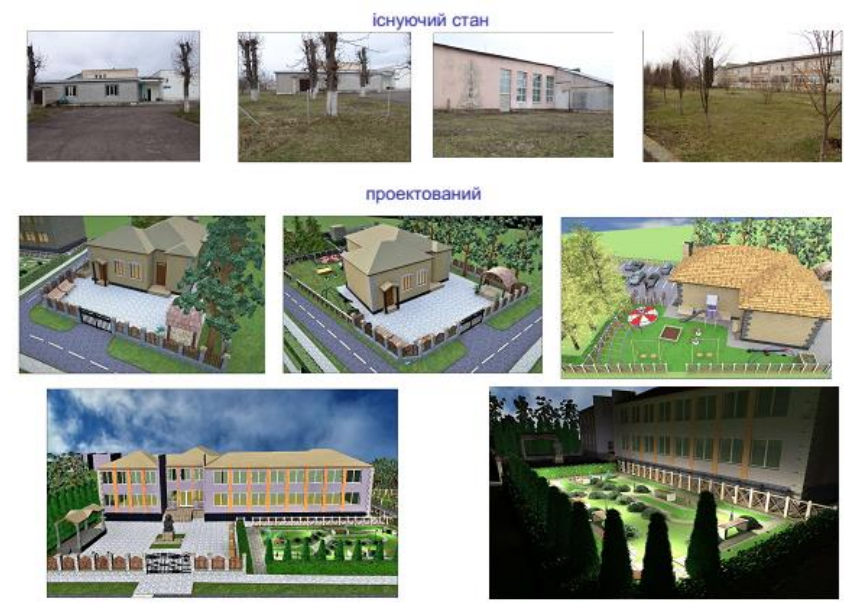

Рис. 1. Елементи формування «сільського публічного простору» в с. Жидичин 
Даний проект створення «сільського публічного простору» передбачає: реконструкцію фасадів клубу та розташованих поблизу будівель; влаштування дитячого майданчику; благоустрій території для зібрань громади; реконструкцію вуличної мережі 3 влаштуванням паркінгу; влаштування відпочинкової зони $[9,10]$.

2. Для створення публічного простору с. Княгининок була вибрана ділянка в центральній частині села на якій розташований центр культури, дозвілля та спорту та приміщення сільської ради $[10,11]$.
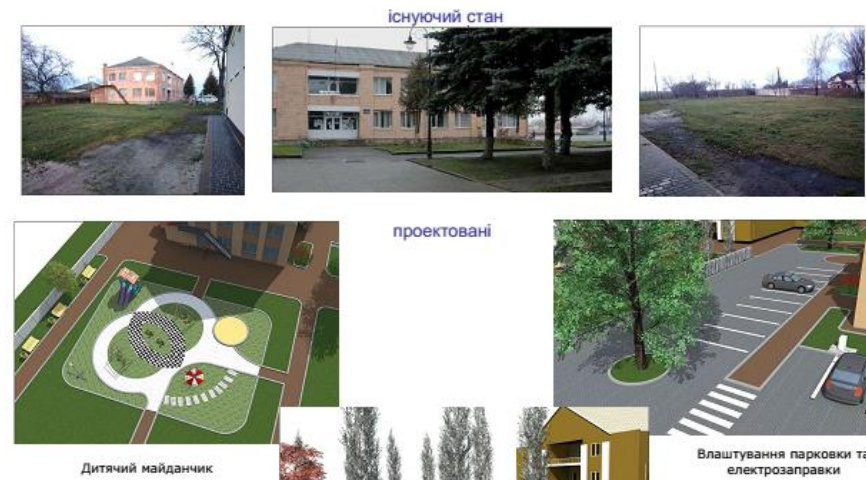

проектовані

Дитячий майданчик

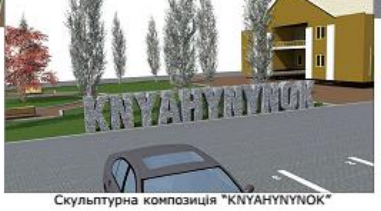

Влаштування парковки та електрозаправки

Рис. 2. Елементи формування «сільського публічного простору» в с. Княгининок

Враховуючи всі аспекти формування «публічних просторів» на даній території було передбачено: влаштування дитячого майданчику; благоустрій території для громадських заходів; влаштування відпочинкової зони; влаштування паркінгу та заправки для електромобілів. Саме таке компонування даної території дозволить дотримуватися основних принципів формування таких об'єктів як «публічний простір».

3. В якості території для створення «сільського публічного простору» в с. Боремель була вибрана його центральна частина. Дана територія відповідає основним принципам формування «публічних просторів». На ній розташовані основні громадські та адміністративні будівлі, а також уже є наявні елементи «публічних просторів», хоча і в занедбаному стані [11,12]. Основними 
об'єктами, новоствореного «публічного простору» є: території для громадських заходів; відпочинкова зона; культурно-спортивна зона; ландшафтно-рекреаційна зона; об'єкти повсякденного обслуговування.

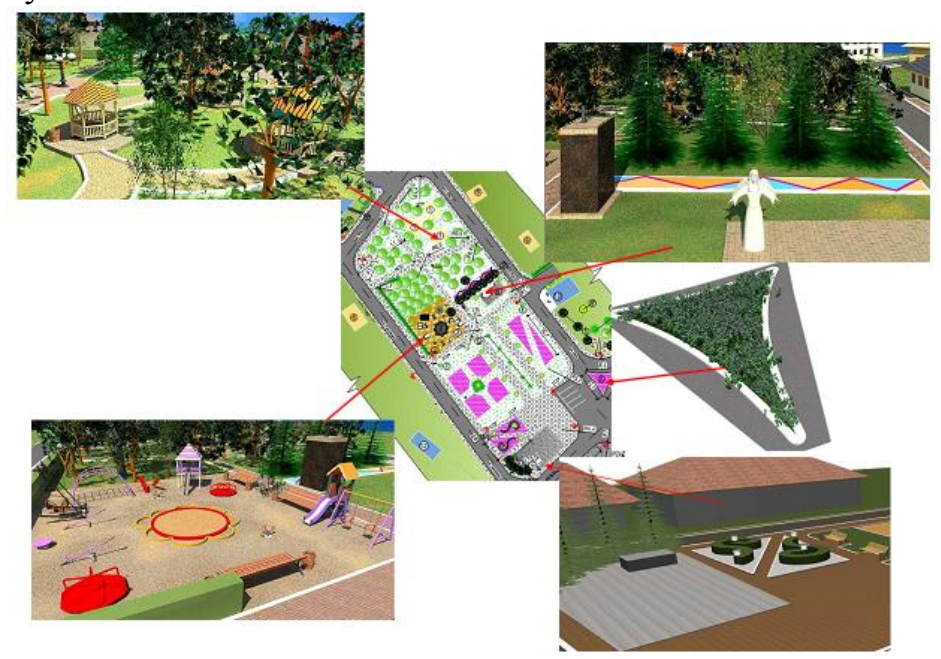

Рис. 3. Елементи формування «сільського публічного простору» в с. Боремель

На сьогодні уже реалізовано проект «Дитячий майданчик місце щасливого дитинства». При формуванні даного «сільського публічного простору» дитячий майданчик $є$ головним центром відпочинку, рухливих ігор, свят, змагань, прогулянок найменших мешканців громади та їх батьків.

Висновки. Отже, основними принципами формування «публічного простору» сіл є: доступність, багатофункціональність, комфортність та безпека, естетичність, соціальність та точка тяжіння.

Представлені в роботі проекти формування «сільських публічних просторів», підкреслюють спільну мету різних територіальних громад покращити можливість функціонування своїх адміністративних центрів.

\section{Список використаних джерел}

1. Децентралізація//Великий тлумачний словник сучасної української мови (з дод. і допов.) / Уклад. і гол. ред. В. Т. Бусел. - 5-те вид. - К. ; Ірпінь : ВТФ «Перун», 2005. - ISBN 966-569-013-2 
2. Євтушенко О. Н. Проблеми децентралізації державної влади і місцеве самоврядування в Україні /Євтушенко О. Н.// Гілея: науковий вісник: збірник наукових праць. 2009 - № 29 - С. 56-60.

3. «АРІВА УРБАН. Твори місто!» [Електронний ресурс] - Режим доступу: https://arivaurban.net/rozdil-golovnoi-storinki/

4. Жулькевська О. Суспільний простір міста як об'єкт соціологічного вивчення та емпіричний референт соціальних змін /О. Жулькевська, М. Грищенко// Соціологічні студії - 2012 - №1 - С. 61-66.

5. Лефевр А. Идея для концепции нового урбанизма [Электронный ресурс] / А. Лефевр // Социолог. обозрение. -2002. -Т. 2. -№ 3. -Режим доступа : http://club.fom.ru/books/doc1607071034.pdf

6. Грищенко М. Публічний простір міста як об'єкт соціологічного дослідження / М. Грищенко // // Вісник Київського національного університету імені Тараса Шевченка. Соціологія. - 2016. - Вип. 1. - С. 3138.

7. М. Коцюба Публічний простір міста. [Електронний ресурс] Режим доступу: https://mistosite.org.ua/articles?locale=uk

8. I. Тищенко. Що таке міський публічний прострір? [Електронний pecypc] - Режим доступу: https://mistosite.org.ua/articles?locale=uk

9. Рощук Т. Ю. Реконструкція та благоустрій центральної частини села Жидичин /Рощук Т. Ю., Кальчевський О.С., Парфентьєва I. О., Мельник Ю.А.// Студентський науковий вісник. Серія "Природничі та технічні науки". Науковий збірник. Випуск 25 . - Луцьк: IBВ Луцького НТУ, 2017.- С. 74-79.

10. ДБН Б.2.2-12:2018 "Планування і забудова територій" - К.: Держбуд України, 2018. - 114 с.

11. Парфентьєва I.O. Особливості формування об'єднаних територіальних громад на прикладі села Княгининок / Парфентьєва I.O., Кошель М.С.// Сучасні технології та методи розрахунків у будівництві: збірник наукових праць - Луцьк: РВВ Луцького НТУ, 2017. - С. 184-191 Сучасні технології та методи розрахунків у будівництві: збірник наукових праць - Луцьк: РВВ Луцького НТУ, 2017. - С. 184-191 . Вип. №7.

12. Олексин Х.А. Вирішення проблем благоустрою та реконструкція центральної частини с. Боремель Рівненської області/ Олексин Х.А., Шевчук Т.В., Парфентьєва І. О., Мельник Ю.А.// Сучасні технології та методи розрахунків у будівництві: збірник наукових праць - Луцьк: РВВ Луцького НТУ, 2017. - С. 167-170 . Вип. №7. 